УДК 39(571.150=161.1)

DOI 10.37386/2413-4481-2021-2-97-118

\title{
В.А. Липинская
}

Институт этнологии и антропологии им. Н.Н. Миклухо-Маклая РАН, г. Москва, Россия

\section{ИЗУЧЕНИЕ РУССКОГО НАСЕЛЕНИЯ АЛТАЙСКОГО КРАЯ МОСКОВСКИМИ ЭТНОЛОГАМИ 1}

Данная статья посвящена рассмотрению экспедиционных исследований Института этнографии АН СССР на территории Алтайского края, проведенных в 1960-1990-е гг. Исследование построено через характеристику исследований культуры разных локальных, социальных, вероисповедальных групп русского населения. Автор подробно останавливается на анализе особенностей поселений, жилища, одежды, обуви, питания каждой из рассматриваемых групп. В заключение автором подводятся итоги работы экспедиций московских этнологов, а также приводятся наиболее важные выводы, к которым удалось прийти в результате полевых исследований.

Ключевые слова: русские, Алтайский край, полевые исследования, этнические группы, Институт этнографии АН СССР.

\author{
V.A. Lipinskaya
}

The Russian Academy of Sciences N.N. Miklouho-Maklay Institute of Ethnology and Anthropology, Moscow, Russia

\section{STUDYING OF RUSSIAN POPULATION OF ALTAI KRAI BY MOSCOW ETHNOLOGISTS}

The article presents the consideration of the expedition research projects of the Institute of Ethnography of the Academy of Sciences of the USSR in Altai Krai, carried out in the 1960s-1990s. The research is structured by the characteristics of the research projects considering cultures of various local, social and religious groups of the Russian population. The author pays special attention to the analysis of the peculiarities of the settlements, households, clothing, footwear, and nutrition of each of these groups. In conclusion the author summarizes the results of the research work of Moscow ethnologists' expeditions and provides the most important findings they made during the field research projects.

Key words: the Russians, Altai Krai, field research projects, ethnic groups, Institute of Ethnography of the Academy of Sciences of the USSR.

Этнографическое изучение русского населения Западной Сибири советскими специалистами началось после того, как в европейской части страны были осуществлены основные исследования, раскрывавшие этническую историю народной культуры. С середины XX в. Институт этнографии АН СССР проводил систематические обследования в различных губерниях с широким охватом природных и историко-культурных зон. Несколько отрядов научных сотрудников вели наблюдения по специально разработанной методике, обеспечивающей получение единообразных материалов и возможность их сравнительного анализа. По результатам работы было опубликовано несколько обобщающих трудов с подробным описанием многих элементов народной культуры на основной территории расселения, не выходившей за границы Уральского хребта. Применение количественных показателей дало возможность составить и издать историко-этнографический атлас [1], который отражал локализацию традиционных элементов материальной культуры и их вариантов, а также показывал изменения во времени от середины XIX в. к началу XX в. Этими фундаментальными трудами были заложены основы для исследований более широкого плана, уже в пределах всей страны.

Южная часть Западно-Сибирского региона являлась конечным пунктом для русских крестьян, уходивших за Уральские горы. Миграция крестьян началась еще в XVI в. и постепенно продвигалась на юг, к Алтайским горам, на изобиловавшие природными богатствами земли. Там сложилась наибольшая плотность населения, в том числе русского. Работа этнографов в Алтайском крае была начата в 1960 году. Выявление особенностей народного быта и культуры русских жителей на юге Западной Сибири поручили двум аспиранткам, каждая из которых самостоятельно собирала материалы для будущих диссертаций по темам:

${ }^{1}$ Статья подготовлена в рамках работы по научному проекту РФФИ и Министерства образования и науки Алтайского края № $19-49-220009$ «Устная история и этнография в полевых исследованиях второй половины XX - начала ХХІ века как источник и метод изучения и сохранения историко-культурного наследия сельских территорий Алтайского края». 
B.А. Липинская «Традиционная материальная культура в XVIII-XX в.» и А.В. Сафьянова «Семейные традиции и изменение положения женщины за годы советской власти» [2-4]. Это были первые специалисты, направленные Институтом этнографии АН СССР за Урал, местные кадры в то время еще не сложились. Молодые исследователи до поступления в аспирантуру уже участвовали в экспедициях и имели опыт этнографических наблюдений. При выезде на Алтай их снабдили ранее разработанными методическими пособиями, что давало возможность в последующем сопоставлять результаты наблюдений в европейской и азиатской частях страны.

В первый рекогносцировочный выезд маленькому отряду (аспирантки, художник и сопровождающий) была предоставлена машина из автобазы Академии наук, переправленная поездом на юг Западной Сибири. В дальнейшем машину арендовали в сибирских автобазах, брали на время в колхозных хозяйствах или передвигались по маршрутам на местном транспорте. Использование автотранспорта позволило охватить обширные пространства и посетить многие населенные пункты, расположенные в разных природных зонах юга Западной Сибири - от таежных лесов до безводных степей.

Основной целью работы отряда этнографов являлось выяснение становления контингента сибиряков на юге Западной Сибири, сохраняющего и развивающего традиционную русскую культуру в новом регионе, удаленном от основной территории. В XIX - первой половине XX в. при изучении Сибири этнографы и историки уделяли внимание более всего местному нерусскому населению, были описаны лишь отдельные обособленные группы русских, получившие особые обозначения. Наш отряд начинал впервые комплексное обследование русских. При предварительном изучении различных источников были намечены три зоны, различавшиеся по природным условиям, составу населения и путям заселения: северо-западная и центральная степная часть с преобладанием переселенцев конца XIX начала XX в.; восточная и северо-восточная часть в прошлом лесная, переходившая в лесостепь, где больше сохранялось первонасельников-старожилов, юго-восточная и южная предгорная и горная часть, где сменялись природные зоны, где сосредоточилось коренное население, с которым имелись непосредственные контакты русских переселенцев. Изучение влияния культуры местных жителей являлось одной из задач, которые стояли перед исследователями. Также можно было ожи- дать воздействия традиций русских старожилов на вновь прибывавших из России. Наконец, все русские, независимо от времени их вселения, должны были адаптироваться к природной среде в зонах нового расселения.

Первый же выезд на юг Западной Сибири показал, что русское население в регионе значительно различалось по составу $[5,6]$. Если в европейской части страны крестьяне стабильно обитали в течение веков на обжитых местах, то в Сибири c XVI-XVII вв. проходило непрерывное пополнение жителей, а также перемещение их по региону в ходе внутренней миграции.

На Алтае, как и во всей Западной Сибири, были выявлены два основных потока мигрантов из европейской части страны: первый (XVI-XVIII вв.), продвигавшийся на юг и восток, был связан с отселениями из севернорусских губерний и от севера Сибири; второй (XIX - нач. ХХ вв.) охватывал все европейские губернии, но более других - южнорусские, из которых крестьяне бежали от помещичьего гнета. В новом регионе прибывавшие потоки отчасти смешивались, и в новых селениях нередко размещались представители разных губерний, но в то же время выходцы из одной деревни могли отстроить отдельную новую деревню. Такая дробность культуры требовала более детального рассмотрения и фиксации выявлявшихся различий, но прежние методические пособия не отвечали нашим задачам. Поэтому для основных элементов народной культуры нами были разработаны новые пособия в форме закрытых бланков, в которых были учтены детали особенностей материальной культуры, выявленные при составлении этнографического атласа «Русские». Наши бланки по поселениям, жилым и хозяйственным постройкам, а также методические указания к их заполнению были опубликованы в сборнике по этнография русского сибирского крестьянства» [7, с. 242-268]. Мы также пользовались «Вопросником для изучения одежды», ранее составленным А.А. Лебедевой (отд. оттиск) и «Вопросником для изучения пищи» Г.С. Масловой (машинописный распечаток), которые давали направления для полевого обследования и программу, по которой собирателю следует вести беседу с информатором.

Разработанные нами методические материалы являлись важным инструментом в экспедиционной работе, помогавшим ее организации и экономии времени, но основными являлись опрос жителей и непосредственные наблюдения. Бланки служили для фиксации объектов. Их заполняли по одному на каждый населенный пункт, на каж- 
дое обследованное строение. В каждом районе по местной статистике выявлялись поселения разных исторических периодов: дореволюционные и возникшие в XX в. В каждом выбранном населенном пункте отбирались для обследования дореволюционные дома (в первый же год мы выяснили, что они составляли лишь 3-7 \% жилого фонда), начала XX в. и его середины. Их численное соотношение должно было прослеживаться по документам местных фондов.

При беседах с информаторами уточнялись детали, делавшие быт жителей специфичным в той или иной мере, и общие традиционные бытовые черты: технические приемы изготовления предметов материального быта, привычки в распорядке дня, приготовлении пищи, обслуживании семьи и хозяйства, отношение к старым вещам и обычаям, наблюдаемые изменения. Учитывая малочисленность отряда и выборочность наших наблюдений, мы считали нужным дополнять их данными местных учреждений, так или иначе фиксировавших бытовые условия. Как выяснилось, таких учреждений было много, при этом разного уровня - от сельских хозяйственных записей до общекраевой статистики. Так, «Похозяйственные книги», имевшиеся в каждом сельском совете, содержали полезную информацию о составе населения и его передвижении. Ежегодный отчет о бытовых тратах семьи отражали «Бюджетные обследования семей» (25 семей разного уровня в населенном пункте). Конкретные данные о вкуcax жителей можно было почерпнуть из отчетов пошивочных мастерских, предприятий общественного питания, магазинов и т. д. Общие сведения предоставляли материалы архитектурных управлений района, а также землепользования и землеустройства, наконец, переписи населения и списки населенных мест характеризовали общую заселенность, информировавшую о расположении поселений на местности, вариативности их названий. Все вместе они позволяли уточнять этнографические наблюдения, получаемые исследователями при полевой работе.

Ценным дополнением этих сведений, а также их иллюстрацией являлись коллекции музеев. Предметы быта более ярких групп старожилов начали собирать еще в дореволюционное время. Эта работа была усилена и расширена в середине XX в. В Алтайском крае были открыты музеи государственного уровня, народные, сельские и даже школьные. Мы ознакомились с коллекциями музея изобразительных и прикладных искусств г. Барнаула, Бийского и Горно-Алтайского краеведческих музеев, ряда народных районных му- зеев (Тогул, Новоалтайск, Славгород), сел Родина, Барановка, Бутаково и с отдельными школьными собраниями историко-краеведческого направления [5]. Полевые и музейные материалы представляют изучаемые элементы культуры не ранее второй половины XIX в., но, к сожалению, далеко не полно, напротив, документы архивов давали более широкое освещение событий в истории русского народа, начиная от времени расселения. Поэтому для освещения ранних этапов освоения земель Алтайского края были изысканы сведения об основании селений, развитии хозяйственной деятельности, создании материальной базы жителей. Для этого изучались фонды центральных архивов (ЦГИА, ЦГАДА, ААН, АГО), западносибирских (ГАТО, ГАНО) и краевого (ГААК). Более всего ценных материалов было получено из ГААК, фонды которого накапливались со времени основания Горнозаводского округа. Извлеченные сведения позволяли раздвинуть временные рамки исследования в пределах от XVIII по конец ХХ в. (до 1991 г.).

В середине XX в., когда были начаты этнографические наблюдения на Алтае, исследователи обнаружили значительное сохранение традиционных элементов культуры и одновременно замещение старинных предметов их современными вариантами промышленного производства. Это требовало углубления исследований на все обозримое время, то есть по трем периодам, которые определили этнографы для европейской части страны (феодальный период - до 1861 г., развивавшегося капитализма - до 1917 г. и строящегося социализма - по 1991 г.). Следовало учитывать также, что Сибирь являлась заселяемым регионом, в котором перед прибывавшими вставали проблемы адаптации в биологическом, этническом и социальном отношениях.

Маршруты наших поездок были построены в меридиональном и в широтном направлениях, чтобы охватить пути расселения, посетить различные природные зоны, обследовать локальные, социальные, вероисповедальные группы русского населения, а также районы контактов с коренными жителями. В первые выезды (1960-1961, 1965 гг.) путь отряда начинался от Барнаула. Местное руководство Алтайского края посоветовало начать работу с передового хозяйства (колхоз «Родина») в Шипуновском районе. Однако оказалось, что центральное поселение (пос. Родина) был создан в 1920-е годы. Поскольку нас интересовало историческое прошлое, отряд пересек территорию края до бывшей пограничной линии в предгорьях, обозначенную ранними крепостями, про- 
ехав Шипуновский, Поспелихинский, Змеиногорский и Чарышский районы. Уже на этом пути определилось, что жители края расселялись в два временных периода: первоначального заселения и последующего уплотнения. Сформировавшееся в ходе каждого потока население получило народные названия: старожилы и переселенцы.

\section{Сибирские старожилы ${ }^{2}$}

Русские люди продвигались на юг Западной Сибири из более северных местностей, где имелись уже постоянные населенные пункты под защитой крепостей. Однако чем дальше к югу, тем опаснее становилась обстановка. Южнее Томской крепости на р. Иртыше и Кузнецкого острога на р. Оби до южной Алтайской горной гряды проходили кочевья местных племен. На них с юга от Монголии совершали набеги более сильные и агрессивные кочевники, которые собирали дань, угоняли скот, уводили людей. От набегов страдали также русские города и деревни. В начале XVIII в. для защиты людей и замирения местности были выстроены укрепления на реках Оми, Берди (1716 г.), Оби (1717 г.), также по Иртышу к его верховьям (Семипалатинская, Усть-Каменогорская и другие), по границам горной гряды (1717-1720 гг.) [8].

Правобережное Прииртышье занимала сухая степь с солеными озерами и мелкими водоемами, что было неблагоприятно для заселения. Восточная часть равнины была покрыта таежными лесами, простиравшимися до хребтов Алатау. Сибирские служилые люди и геодезисты разведали, что места вблизи устьев рек Бии и Катуни пригодны для пашен, обильны для охоты, обеспечены реками. В 1718 г. на р. Бие в сосновом бору было построено новое укрепление, где позже появился г. Бийск. Под его защитой началось самовольное расселение по южной Сибири, что привело к появлению постоянного русского населения и формированию его местных групп.

\section{Сибирские линейные казаки}

Старейшими жителями Западной Сибири, в том числе и Алтайского края, являлись казаки Алтайской казачьей линии, переведенные из более северных сибирских укреплений. Казачество представляло особую сословную группу. Оно разделялось на отряды городовых и линейных казаков. Городовые казаки, в прошлом защищавшие города-крепости, к XVIII в. стали выполнять полицейские функции и являлись привилегированной частью городских жителей. Линейные казаки были близки к крестьянству, имели земельные наделы, которые сами и обрабатывали. По воспо- минаниям населения, в небольших поселках они в прошлом по бытовым условиям почти не отличались от крестьян: жили в небольших избах под соломенными кровлями, женщины носили рубахи и сарафаны.

Положение казачества изменилось после 1840 г., когда было создано закрытое казачье сословие. Линейным казакам были выделены земли (так называемые юртовые) для хозяйственных наделов в три раза большие, чем для крестьян, к тому же обширные выпасы и места рыбных ловлей. Благосостояние казаков быстро повысилось, что сказалось на их хозяйственной деятельности, изменило бытовую культуру, отразилось в самосознании. Казачество стало противопоставлять себя крестьянству. В среде городовых казаков появилась интеллигенция, включавшаяся в исследовательскую, в частности этнографическую, деятельность. Именно в среде городских казаков возникло «областничество», выступившее за обособление Сибири на правах автономии и даже за отделение от России.

Наш отряд проводил наблюдения в поселениях линейных казаков Алтайской линии: с. СтароАлейское, пос. Верх-Алейский, с. Чарышское и мелкие поселки (районы работ - Змеиногорский, Третьяковский, Чарышский районы) [5, 6]. Пожилые люди еще хорошо помнили свой весьма благополучный быт в начале $\mathrm{XX}$ в. и кое-что из истории группы.

Сельское линейное казачество развило интенсивную хозяйственную деятельность полеводческо-животноводческого направления. Используя крестьян как наемную силу, казаки увеличили доходность хозяйства. Они стали инициаторами развития полеводства, бахчеводства, табаководства и пчеловодства. Всё это со своей стороны выделяло их среди других сельских жителей, внося изменения в материальный быт.

Поселения, постройки. Войсковая администрация казачества считала необходимым утвердить единообразие во внешних формах, начиная от поселков и жилищ. По линии разосланы планы, в которых было рекомендовано прямолинейное расположение улиц с четкими прямоугольными угодьями, разделенными на «чистый» и «хозяйственный» дворы. Амбары стояли на усадьбах, а скотные дворы вынесены на околицу. Вблизи станиц отстраивали лагеря для подготовки молодых казаков, где были казармы и «плац» для занятий. Жилые дома рекомендовали строить связью (изба + сени + изба). Этнограф Г.Н. Потанин опи-

\footnotetext{
${ }^{2}$ Районы работ 1960-1961, 1965 гг.: степная равнина (Шипуновский, Мамонтовский, Горьковский, Поспелихинский районы), лесостепное предгорье (Змеиногорский, Третьяковский, Чарышский районы).
} 
сал в ст. Чарышской именно этот план [9, с. 7980]. Каждый дом состоял из избы и горницы, разделенных сенями, имевшими двери на улицу и во двор. Такая же планировка преобладала и при нашем посещении этого населенного пункта (1965, 1991 гг.). На выявленном нами в архиве плане станицы в середине XIX в. связных домов указано более $80 \%$, среди них имелось немного усложненных коридором, были показаны и отдельные пятистенки. В XX в. значительно увеличилось количество пятистенных домов - более удобных для малых семей и экономных по расходу материала.

Костюмы. Перемена статуса казачества наиболее ярко отразилась в одежде. Мужчины приобрели военизированную форму коричневого цвета, к ней полагалась шинель и теплушка (подстежка). Фуражку надевали по праздникам с кокардой, летом от выгорания закрывали ее чехлом. Для зимы имелись шапки-ушанки, богатые шили и папахи. Для поездок в холодное время использовали башлык. В состав повседневной одежды входил колпак.

Женщины получили возможность отказаться от домашнего ткачества и перейти на городской костюм того времени из промышленных тканей парочку (юбка и кофта) дополнял платок. Казачки стали проводниками городских фасонов в крестьянской среде, следуя имевшейся моде.

Обувь в казачьих селах признавалась только кожаная - сапоги мужские и женские. Молодежь и в этом следовала моде: юноши стремились купить хромовые сапоги, носили их с подковками, собирали голенища в «гармошку». Девушки щеголяли в ботиночках на каблучке и со шнуровкой. Зимой надевали валенки, в праздничном варианте - белые с красной вышивкой. Также и в годы советской власти, перейдя к общераспространенному готовому платью, казачки стремились поддерживать престижность в одежде.

\section{Крестьяне-старожилы верховьев р. Оби}

Заселение Алтайского края крестьянами начиналось с северо-восточной части. Самовольное продвижение русских шло от Бердского и Кузнецкого острогов в лесистых предгорьях Салаирской гряды [8]. Наблюдения этнографов в этой местности были проведены в 1970-1980 гг.

Как было выяснено, первые небольшие деревни стали появляться в конце XVII - начале XVIII в. Расселение проходило волнами, через разведывание угодий заимками - пробными участками хозяйственного назначение (под пашни, сенокосы, выпасы). Заимки стали местной сибирской систе- мой землепользования и одновременно местным способом расселения.

Поселения. Первые деревни по рекам Тогул, Чумыш и др. основывали выходцы из Кузнецкого уезда, создавая редкую сеть населенных пунктов, расширявшуюся заимками. Так, из д. Титово, основанной однофамильцем, младшее поколение основало более десяти новых деревень (устное сообщение историка Ю.С. Булыгина) [8]. Из них до настоящего времени сохранились Озерно-Титово, Дмитрово-Титово. Среди засельников местности преобладали старообрядцы, укрывавшиеся от административных преследований.

Южнее Кузнецкого острога проходили кочевья коренных жителей, которых русские называли кузнецкими татарами. Кроме крестьянских заимок на равнинах были созданы сторожевые поселения (форпосты, защиты), которые после замирания местности были переведены в крестьянские поселения (форпосты Сайдып, защиты Солтонская и др.). Южнее на плоскогорьях проходили кочевья алтайских племен. Их земли были обозначены как ясашная волость, официально закрытая для русского расселения. Однако крестьяне в удобных местах устраивали заимки по рекам Иша, Майма, которые потом развивались в деревни. Во второй половине XIX в. в лесную часть стали прибывать российские переселенцы. В Сайдып, например, вселились выходцы из Вятской губернии, в Сузон - из Вологодской, Пермской, Вятской губерний. Часть старожилов уходила дальше в горы на запад по р. Катунь и притокам Песчаной, Карагай, Ануй и др., которыми заканчивался бассейн р. Катуни.

Жилище. В строительстве первонасельников преобладали севернорусские традиции. Поселяясь в густых лесах, старожилы рубили избы из столетних сосен или лиственниц, их ставили на высоком подклете (6-8 венцов, стены до 18-23 венцов) под 2-4-скатными тесовыми крышами. В подклете оборудовали подполье с завалинкой для хранения овощей. Нередко половину нижнего помещения отводили под мастерскую или жилье, а в XIX в. - также и под торговую лавку со входом в боковой стене или по фасаду. Из избы вход в подполье вел через люк в полу, над которым в старину пристраивали у печи небольшой шкаф - шолныши (голбец), как на европейском севере, а в первой половине XX в. его место занял низкий голбец в виде ящика. К концу века тот и другой были вытеснены люком в полу, как в центральной части страны (от 30 до 90 \% по

\footnotetext{
${ }^{3}$ Районы работ: 1978 г. - Крутихинский район (с. Крутиха, Волчно-Бурла, Тележиха, Прыганка), Солонешенский район (Солонешное, Топольное, Екатерининское); 1979 г. - Усть-Пристанский район (ст. Борда, Кораганка, Камышенка), Усть-Коксинский район (Саввушка, Старая деревня); 1980 г. - Тогульский район (Старый Тогул, Топтушка, Колывань); 1988 г. - Солтонский район (с. Солтон, Сайдып, Излапт, Сузон).
} 
деревням). В селениях старожилов в ХХ в. практически не осталось изб, распространены были дома связью и крестовики, встречались крестовые связи, в том числе двухэтажные. Развитию жилищ благоприятствовало увеличение доходности крестьян после водворения переселенцев, нуждавшихся в заработках для пропитания, и всплеска торговли на вновь проложенных трактах. Вместе с переселенцами приходили артели строителей и с ними красильщики, владевшие искусством росписи. До конца XX в. в этой части региона сохранялись «крашеные дома» богатых старожилов, с рисунками, выполненными масляными красками по деревянным стенам избы и горницы. Дома уже были ветхие, краски облезли и облупились. Владельцы домов помнили, что рисовали мастера, приходившие из Тюмени с артелями плотников. Основным сюжетом росписи были цветы в различных композициях, сходные с росписями в других районах Западной Сибири и Урале. Однако дома, в которых сохранялись рисунки и сами изображения, были уже весьма обветшавшими.

Одежда. Не в лучшем состоянии находился и традиционный костюм (рис. 1). Жители могли охарактеризовать его на период 1920-1930-х годов, когда уже не сохранилось отличий между старожилами и переселенцами, так как распространился городской костюм: юбка с кофтой для женщин (рис. 2), косоворотка и брюки (щарова$p a)$ для мужчин. Местные краеведческие музеи успели собрать небольшое количество предметов традиционного комплекса (рис. 3).

Как удалось выяснить, в конце XIX - начале XX в. старожилы использовали для одежды сравнительно немного домотканины, преимущественно для рабочих надобностей, так как поступало много фабричных, в том числе и зарубежных, тканей (китайка, даба, а также атласы и бархаты).

Женский комплект одежды соответствовал севернорусскому комплексу: рубаха с прямыми поликами, сарафан (из тонких тканей, его носили с юбкой), нарукавни с цельным передним полотнищем или на кокетке (рис. 4).

В головных уборах также сохранялись старинные, но различные традиции. Общими являлись платок или шаль. Девушки свертывали их в ленту и повязывали узлом, свешивая концы по спине. Женщины покрывали платком другие головные уборы, закрывавшие волосы. Для девушек невест особый покров был отмечен в форме колпака. Этот вариант был шире распространен в южной части России, в том числе у казачек, был известен он и в центральной части, встречался в Западной Сибири.
Замужние женщины на Алтае закрывали волосы мягким волосником - самшурой (шамшура, шашмура), бытовавшим в Сибири в двух вариантах: с закрытой макушкой или с открытой. Шамшуру первого варианта шили с плотным очельем, придававшем красивый контур голове. Такой волосник был известен на европейском севере, распространен в Приуралье. Другой вариант шамшуры, весьма упрощенный, состоял из полоски ткани, сосборенной на вздержке по верху и понизу, завязывавшейся сзади. Поверх шамшуры надевали шапочки из атласа и бархата с подкладкой, которые надевали кичкой или кокошником. Они были элементом традиционного костюма, хотя покрой сходный, термины были принесены и из северной, и из южной частей страны. К кокошнику подвязывали сзади позатыльник из позумента, украшенного понизу кистями из бисера или стекляруса. Такие подвески служили украшением убора как на севере, так и на юге страны.

$B$ мужской одежде для повседневности шили рубаху и штаны из холщовой ткани, и для праздничного костюма брали дорогие атласы и бархаты, а также - замшу, кожу и меха. По покрою одежда в этой группе не отличалась от носившейся другими старожилами Западной Сибири, однако в селениях, приближавшихся к ясашной волости, использовали больше меха.

C конца XIX в. наиболее популярной одеждой мужчин стала рубаха-косоворотка на выпуск с воротником-стойкой и штаны русского покроя (из трех полос). Как рабочую одежду шили широкие штаны-чембары из четырех полос, с вставкой посредине. Их можно было натягивать даже на верхнюю одежду. В суровом климате Сибири чембары использовали также и в других местностях как мужчины, так и женщины.

Костюм подпоясывали тканым или плетеным поясом (рис. 5). Мужские пояса выполняли также, как женские, но кисти часто заменяли бахромой. Различали узкие пояски, неширокие пояса поверх рубах и широкие опояски для верхней одежды.

В начале ХХ в. в моду вошли рубахи с кокеткой и также со стоячим воротником, с разрезом справа или слева. К кокетке нижнюю часть пришивали, расширив ее вставными бочками и сосборив вверху по шву. Рукава также стали делать более широкими, присборивая их в плечах и у манжета.

Голову мужчины летом покрывали соломенной шляпой или войлочной шапкой с округлым верхом. Зимой теплые шапки подбивали ватой, делали меховую опушку. В XIX в. все варианты легких головных уборов стал вытеснять картуз с плотным козырьком. 
Обувъ в Сибири в повседневном и праздничном обиходе была кожаная, одинаковая для мужчин и женщин. Дома обычно носили мягкие обувки или коты из "скотской» кожи местной выработки. По форме они были сходны с головками сапог. Внутрь укладывали мягкую стельку, по верхнему краю обшивали опушкой, через которую продевали шнурок-вздержку. На улице ходили в сапогах. Для работы у мужчин имелись высокие сапоги-бутылы и бродни, с мягкими голенищами, которые подвязывали у колен. Молодые щеголи надевали сапоги с дополнительно пришитой подошвой. В начале XX в. девушки стремились приобретать модные полуботинки и полусапожки со шнуровкой. Зимней обувью повсюду в Сибири были $n u м b l$ в том числе праздничные - белые с красной вышивкой. Обувь носили с протяными и шерстяными носками, гуляками. По-видимому, от местных скотоводов русскими была воспринята меховая обувь: лунты (унтьь) - сапоги из шкурок с козьих ног, кисы - короткие меховые носки.

Верхнюю одежду шили из различных плотных тканей: толстой холщовой, полушерстяной (понаток), суконной домашней валки или покупной, а также из меха своей выделки, из кожи (или замши). В Сибири сохранялись до XIX в. древние одежды прямого покроя или халатообразного, кафтанообразного: пониток (по названию ткани) или шабур, из полусукна - сермяга (из грубого сукна), зипун из сукна. На такого же покроя азям использовали покупную верблюжью шерсть, его нередко покупали готовым у коренных жителей, что было распространено также в Поволжье. Кафтаны появились позже из европейской части страны. Их шили с частичным разрезом по талии и с расклешем. Местный вариант такой одежды с прямыми полами и со сборками по бокам и по спинке называли сибирка.

Сибирский климат требовал защиты от холода, поэтому как мужчины, так и женщины носили разнообразные меховые изделия, зачастую домашней выработки, но было налажено и заводское производство. Верхняя одежда различалась по длине в зависимости от назначения. В повседневном быту преобладала форма покроя ниже колен. Полушубки шили из овчины с подрезом по талии. Их делали нагольными, окрашенными (дублеными) или покрытыми тканями. В Барнауле разработали метод дубления, дававший красивый окрас и большую прочность. Полушубки местной выработки, названные барнаулками, прослаивались по всему региону. Наиболее надежным для согревания в дороге считали тулуп длиною в пол с большим запа́хом и широким воротником, которым можно укрыть голову. Их шили большей частью из овчины, но выделывали также шкуры маралов, горных козлов (яманов) и даже собак.

В начале XX в. появились новые варианты одежды из фабричных тканей: мужские суконные куртки, женские пальто с протяженной подкладкой - сак и укороченный (выше колен) - полусак. Их носили в течение всей первой половины XX в. повсюду в стране, а местами в Сибири и дольше. Во второй половине XX в. практически все виды одежды, бытовавшие до этого, заменили новые варианты аналогичной одежды из современных тканей, в том числе из искусственного меха.

В питании крестьян произошли резкие перемены после прибытия переселенцев из южно-русских губерний. Первые насельники Сибири принесли севернорусские традиции полеводства с преобладанием зерновых, выдерживавших климат северных широт. Соответственно, питание строилось на основе мучных и крупяных изделий из ржи и ячменя: пекли черный хлеб ковригами, варили толстые щз из ячменной крупы, к которым добавляли немного мяса по скоромным дням. До середины XIX в. удерживались также древние блюда: затир$\kappa и$ или болтушки из муки, заваренной в кипятке, а также слепленные из теста рванцы, клецки, лапша. Старожилы делали из овса толокно, входившее в ежедневную трапезу и служившее дорожным запасом легкого приготовления. Это был высококалорийный продукт питания, сложный в изготовлении, но сохраняющийся на длительное время. Толокно было хорошо известно на европейском Севере, включая Прибалтику, а русскими было распространено еще и по Сибири.

Мясо-молочный стол был разнообразнее. При том что леса изобиловали зверями и дичью, а реки кишели рыбой, скота местных пород держали много, хотя из-за длительных постов мяса ели мало, обычно в отварном и тушеном виде. Старообрядцы относились к выбору пищи настороженно: свинину избегали из-за всеядности животных, считали греховным есть мясо парнокопытных и некоторые сорта рыб. Много мясной и молочной пищи запасали на зиму; мясо вялили, молоко замораживали, рыбу солили, вялили, морозили, коптили.

Крайне слабо было представлено овощеводство. Как полевые культуры растили капусmy, peny, горох. Остальной небогатый набор северных культур был огородным, в том числе картофель. Дополнительно к этому использовали дикорастущие и запасали на зиму разные виды лука, чаи, ягоды, особенно черемуху, плоды которой толк- 
ли в муку для варки киселей. Орехи же, особенно кедровые, заготавливали мешками на весь год и вывозили на ярмарки.

На землях, освоенных старожилами в предгорьях, были найдены полезные ископаемые. Уральский промышленник А. Демидов в XVIII в. построил металлургические заводы. Для их обслуживания «приписывали» крестьян из окрестных деревень, что создавало дополнительные трудности в хозяйственной деятельности. Нерудные породы использовали при строительстве, в горах обнаружили залежи полудрагоценных камней (яшма, порфиры, агат и др.), которые использовались как декоративные. В 1802 г. в с. Колывань открыли шлифовальную фабрику, изделия которой (вазы, украшения, бытовые предметы) пользовались спросом. Крестьяне и рабочие мастерских отходы производства применяли в домостроительстве. В начале XX в. российские переселенцы открыли в с. Колывань гончарную мастерскую, работавшую по более совершенной технологии (ножной круг, обжиг в горне, полива). Изделия мастерской поступали в обиход также и старожилов, до того лепивших посуду на ручном кругу.

Еще большее значение имели новые культуры в полеводстве и животноводстве, доставленные переселенцами из южно-русского региона. Перемена направления хозяйства на преобладание пшеничного поля сделала сибиряков основными поставщикам хлебной продукции в регионе. Одновременное улучшение породности от привезенного скота повысило надойность молока, которое было признано по качеству лучшим в стране. В начале XX в. усилиями маслоделов из европейской части страны было начато производство товарного сливочного и топленого масла. В эту доходную деятельность включились также старожилы. Общие усилия вывели сибирское маслоделие в лидеры мирового экспорта.

Начало XX в. стало периодом расцвета хозяйства и бытовой культуры крестьян лесостепной части Западной Сибири. Заложенные в этот период достижения стремилось продолжить советское государство, однако в бытовой культуре до конца XX в. сохранялись вкусовые особенности как у потомков старожилов, так и у переселенцев, что было более ярко выражено в семейной кулинарии.
Старообрядцы южного пограничья: «поляки", каменщики (бухтарминцы, уймонцы $)^{4}$

Расселение. Горная местность, отведенная администрацией Алтайского округа для коренных жителей (ясачная волость), была официально закрыта для русских. Поэтому крестьяне-старожилы, искавшие свободных земель, минуя ее, начали продвигаться к западу, вдоль горных хребтов в бассейн р. Катуни. Это были последние поиски новых угодий, начатые в XVII в.

Бегство «в камень», то есть в горы, началось вскоре после постройки промышленником А. Демидовым первого завода. Работали на нем переведенные с Урала мастера, а обслуживать в качестве подсобной силы обязали поселившихся в этой местности крестьян. Они неожиданно для себя оказались на казарменном положении, уход из селения считался «бегством», на розыск направляли воинские отряды. Первые тайные поселения избы - были выявлены в 1756 г. возле р. Ини, но посельщики ушли. С того времени обнаруживали деревни на реках Кок-Су, Убы, Ульбы. В 1780 г. до 10 изб отметили на р. Бухтарме и ее притоках. Эта группа оказалась устойчивой и разрасталась. В 1927 г. несколько селений, возникших в долине реки, обследовали этнографы ленинградского отдела ИЭА РАН, посвятившие их описанию отдельную монографию [10]. По местным легендам, от Бухтармы отселялись на другие реки, в частности на р. Аргут и Уймон. Группы в горах называли каменщциками, в них с наибольшей яркостью проявлялись адаптивные способности жителей. Наши исследования, как и наблюдения ленинградцев, показали, что группы в горах были изолированы в силу естественных условий, но между ними прослеживались и родственные связи через отселения, что объясняет наличие общих черт быта в заселках по разным ущельям.

В начале XX в. русская церковь начала миссионерскую деятельность в кочевьях алтайцев, склоняя их к оседлости, также было разрешено поселение вблизи алтайцев русских крестьян для обучения кочевников земледелию. Пользуясь этим, крестьяне выдвинули на окраину волости заимки, а потом основали и новые деревни. Так, в 1928 г. появились Улала (ныне - Горно-Алтайск), Майма, Чемлай, Черный Ануй и др. Их жители пополняли ряды каменщиков.

Иначе происходило заселение горных длин в правобережье верховьев Иртыша. В XVIII в. кре-

\footnotetext{
${ }^{4}$ Районы работ: 1979 г. - Усть-Канский район (Катанда, Мульта, Шебалино); 1980-1988 гг. - Лениногорск, Усть-Каменогорск, Колывань, Лосиха, Тюдрала, Каракол, Черный Ануй, Белый Ануй; 1990 г. - Алтайский район (Майма, Ая, Туорак, Усть-Кумир, Коргон, Белокуриха); 1991 г. Чарышский район (Чарышское, Тулата, Аба, Генералка, Сентелек).
} 
стьянское расселение перешагнуло линию пограничных укреплений Алтайской казачьей линии. По решению администрации укрепления перенесли глубже в горы, создав новую линию. В освободившихся поселениях между Змеиногорской и Усть-Каменогорской крепостями разместили большую группу ссыльных старообрядцев от западных границ России, их позднее назвали поляками. Часть сосланных поселили в горах для обслуживания местных заводов, там появилась Риддерская волость. Две части группы оказались в разных природных условиях, но обе вблизи казаков, беглых крестьян и кочевий алтайцев. Так, в горах сомкнулись движения с востока и с запада. Тех и других объединяла стойкость в сопротивлении новообрядчеству.

При этом каждая группа стремилась к сохранению внешней изолированности и своего вероисповедального единства. Наши опросы и проанализированные акты гражданского состояния показали, что браки заключались до революции преимущественно в своей группе. Также, по подсчетам антропологов, в конце XX в. в крупных селах «поляков» было выявлено лишь $10 \%$ жен, включенных из других групп. Однако прибытие переселенцев из России нарушило единство сложившихся поселений старообрядцев. В горы стали прибывать старообрядцы других толков. Так в д. Лосихе к старожилам поморского толка подселились австрийцы (окружники и противоокружники, федосеевцы, самодуры и единоверцы). Поселенные списки переписи 1897 г., просчитанные нами, выявили в каждом населенном пункте по нескольку старообрядческих толков. У каждого имелось свое маленькое кладбище. Все они были снесены после установления советской власти.

Постройки. На юге Алтайского края представители всех собравшихся в этой местности групп населения возводили жилище в севернорусских традициях: срубный дом на подклети и под тесовой крышей. При этом в каждой группе наблюдались особенности, возникавшие под воздействием природных условий или социально-исторических обстоятельств. Так, «поляки», поселенные в освобожденных казаками поселках, продолжали строительство домов типа «связь», иногда с коридором, а наиболее зажиточные в конце XIX в. возводили двухэтажные крестовые связи. Горные поселения демонтировали разнообразие народного зодчества: от одиночных изб в начале застройки через пятистенки и связи к огромным двухэтажным связям с подвалами, боковыми коридорами, балконами и галереями. При этом в горных селе- ниях, где много снега, подклети были высокие, а у равнинных «поляков», прибывавших из сравнительно теплого региона, подклети, соответственно, пониже (2-4 венца).

Стены срубов внутри дома слегка обтесывали, чтобы подровнять поверхность, а с конца XIX в. быстро распространялась домовая роспись. В потоке переселенцев прибывали в Сибирь мастера плотники и с ними красильщзик. Разбогатевшие старожилы не скупились на украшении жилища. На юге Западной Сибири сложился яркий очаг домовой росписи. Исследователи пытались выяснить ее истоки, находя их от Украины до Средней Азии, но со временем выяснилось, что в конце XIX - начале XX в. процветал обширный район крестьянской живописи, включавший Приуралье, Поволжье, юг Западной Сибири и уходивший в Восточную Сибирь. Ее характерными чертами являлись: рисунок маслом в свободной кистевой манере с отбелками и разживками. Основу рисунков составляли цветочные гирлянды и венки, круги и букеты, горшочные композиции или россыпь, с обязательным присутствием многолепесткового розана. Эти орнаменты дополняли изображения птичек (летящих, сидячих, поющих), реже встречались образы льва и коня, а также бытовые сцены. У «каменщиков» яркая роспись сохранялась до середины XX в. В мастерство включались также и местные жители.

Наружный декор домов был намного слабее. Небольшая пропильная резьба украшала подкарнизные доски, но основные нагрузки принимали наличники. В резьбе сочетались долбленые и пропильные узоры, в большинстве они повторяли известные в европейской части мотивы: долбленая розетка, накладные полуколонные кисти, а также пропильная резьба с изящными завитками украшали навершия наличников и подкарнизные доски. Пропильную резьбу в городах и крупных селениях накладывали на угловые срезы срубов, а в сельском декоре появились новые мотивы, которые в основном накладывали на наличники: косари (завитки хвоста тетерева), рога барана или оленя, сосновые шишки и т. п. Большинство наличников и ставень оставались без декора, но нередко покрывались масляной краской. К наружному декору относится также оформление балясинами крылец, балконов, галерей. Их делали двух типов: точеными или вырезными из досок. Изредка рельефы помещали на ворота и калитках усадьбы. Однако в большинстве горных деревень усадьбы огораживали пряслом (жердями, укрепленными в столбах). Зажиточные крестьяне ставили у входа ворот- 
ные столбы, ограду делали из теса или полубревен, забранных в столбы.

Усадъбы по размерам и застройке значительно различались в горных и равнинных селениях, что непосредственно определялось природными условиями. Хотя направление хозяйства было полеводческо-животноводческим, что требовало наличия определенных традиционных помещений. Усадьбы повсюду в России разделялись на чистый двор, где стоял дом, и скотный двор для животных, которых помещали в срубном дворе. Однако в горах преобладающая роль отводилась скотоводству. Крупного молочного скота держали много, но на усадьбах находились лишь дойные коровы и молодняк. Основные стада круглогодично пасли в «отгоне» на зеленых кормах. Поэтому на усадьбе срубные дворы заменяли пригоны - огороженный участок, закрытый заплотом с наветренной стороны, иногда с навесом. В небольших крытых постройках держали лишь молодняк, мелкую скотину и птиц.

Русские крестьяне начали приручение маралов, которых местные жители до этого убивали ради получения рогов, продававшихся в Китай. Приручившие маралов содержали их в маральниках или садаx - больших огороженных участках в стороне от селения. Там отгораживали пригон для подкормки животных и ставили избушку для сторожа. В советских колхозах был сконструирован станок, в который загоняли марала и срезали рога без вреда для животного. Из рогов вырабатывали лекарства, являвшиеся экспортным товаром.

Полеводство в горных селениях сохраняло севернорусские традиции, принесенные первыми насельниками. Сеяли ячмень, рожь, овес. Пшенице отводили небольшие участки на южных склонах гор, но и там колосья не успевали созревать полностью, поэтому на усадьбах для подсушивания злаков сооружали настил - сушило. В прошлом имелись овины и клуни, догнивавшие в лесах после распространения новых сортов зерновых.

В равнинной части юга Западной Сибири на черноземных полях хлебопашество заняло первое место. Ограниченные замкнутые усадьбы, как в средней полосе России, имели обширный чистый двор, где кроме дома размещались один или несколько амбаров, завозня, за ними большой срубной скотный двор с пригоном. В зависимости от местности появлялись однорядные и двурядные варианты и особая охватывающая застройка.

В севернорусской культуре традиционным являлось наличие бани. Они имелись в Сибири почти в каждом селении. На юге Алтая бани ставили обычно за оградой усадеб у реки. С конца XIX в. «черные бани» начали заменять на «белые» и переносить ближе к дому. В горной местности даже в 30-х годах XX в. имелись старинные маленькие черные бани, сохранявшиеся по берегам рек.

Таким образом, традиционность культуры в севернорусском ее комплексе четко проявлялась в постройках на крайнем юге Сибири, но некоторые элементы в горных селениях уходили из быта как невостребованные, другие сохранялись в упрощенной форме, появлялись и местные самобытные варианты, продиктованные условиями природной среды.

Одежда ярче всего представляла группу каменщиков, в которой сложилась яркая самобытная традиция, ставшая знаковым элементом культуры. При этом комплекты одежды мужчин и женщин по составу и основному покрою вполне соответствовали народным обычаям.

Женская одежда была представлена у предгорных «полячек» и горных групп общим сарафанным комплексом (сарабан, рубаха), присущим севернорусскому региону. Однако в южноалтайской местности наблюдались некоторые отличия и своеобразие, проявлявшиеся в вариативности и в особых деталях. Одежду в прошлом шили из домотканого полотна, но рано были налажены торговые связи с новыми соседями (китайцы, казахи, бухарцы), поставлявшими ткани лучшего качества. Из них самым грубым являлась китайская плотная даба, самыми тонкими и яркими - восточные шелка.

Женские рубахи по традиции были составными, верхняя часть (чехлик, рукава) - из более хорошей ткани, преимущественно покупной, а нижняя (подстава) - из холста. Рубахи шили преимущественно в севернорусской традиции с прямыми поликами и тастовицами. Рукава из двух-полутора полотнищ пришивали к поликам и стану, внизу собирали на вздержку. У «поляков» бытовали более широкие рубахи, у которых чехлик кроили по утку, что имело сходство с южнорусской традицией (рис. 6). Рукава из двух полотнищ разной длины сшивали, загибая верхнюю часть внизу кулем, что создавало объем внизу рукавов. Все полотнища в верхней части рубахи собирали на вздержку (боры), оставляя прямой разрез посередине. К вороту пришивают неширокий отложной воротничок (ощейник), что связывает с традициями западнорусского региона, Белоруссии. Верхнюю часть рубахи нередко оформляли как отдельный элемент одежды (рукава), которые носили с сарафаном. Если ткань рукавов и сарафана совпадала, костюм называли парочка. Швы, соединявшие различные части рубахи, сшитой из полотна, а также воротник и манжеты украшали 
полосками вышивки геометрическим орнаментом (рис. 7) красными и черными нитками. В места соединения частей рубахи нередко вставляли узкую полоску кружева домашнего плетения, выполненного с помощью иглы. В рубашках из цветных тканей вышивки не было, но цветную кружевную плетешку вставляли.

Сарафаны были основной наплечной одеждой, надевавшейся поверх рубахи. До конца ХХ в. можно было наблюдать разные покрои, отражавшие последовательные изменения этой одежды. Самый древний вариант сшила худенькая старая женщина как свою смертную одежду. Покрой был туникообразный со швами по бокам и небольшими вырезами для горловины и пройм. В комплект входили чепчик с завязками и шапочка. В повседневном быту конца XIX - начала XX в. носили косоклинные сарафаны. Более старой формой считался покрой с одним передним и одним задним полотнищами, дополненных боковыми клиньями из полотнища, разрезанного по косой. Этот покрой был известен в прошлом также и в европейской части страны. Большее распространение получили косоклинные сарафаны с двумя передними полотнищами, соединенными швом, и с одним задним и с пришитыми к нему боковыми клиньями. Часть шва спереди вверху не сшивали, а застегивали на пуговицы, нередко разрез имитировали. Эту часть одежды украшали лентами, позументами, красивыми пуговицами. Сарафаны держались на плечах на лямках, для которых в прошлом оставляли специальный выступ на спинке. Косоклинные сарафаны такого покроя были широко распространены в прошлом на европейском Севере и в Приуралье.

В конце XIX в., как и повсюду в России, косоклинные сарафаны замещали на прямые. Первыми перешли к этому «поляки» предгорной части, а в горной местности появился новый покрой лишь в 1930-е годы. При полевых наблюдениях были выявлены различные переходные формы. Изменения заключались в увеличении числа полос прямой ткани и в густоте и расположении сборок (от присборивания на груди до круговых по периметру). Все варианты сарафанов носили с длинными поясами (плетеными, ткаными, вязаными, украшенными кистями), ими дважды обвивали талию и завязывали на боку. На юге Алтая в конце XIX в. у старообрядцев поморского толка бытовала одежда в виде цельного платья - горбачи. Покрой нам описали в с. Б. Бащелак Чарышского района, но само платье не сохранилось. По сообщениям, жителей горбачи шили из четырех прямых полос ткани, закладывая складки в одну сторону - слева направо, имелись длинные рукава и воротничок небольшой стоечкой с застежкой спереди. В XX в. горбачи как старинная одежда были отмечены у старообрядцев в Вологодской области, а также у старожилов в Приморье и Приуралье, что указывает на связи с севернорусским регионом. В комплект из сарафана и рубахи входили также нарукавники севернорусского покроя, но с более широкими рукавами, что ближе к южнорусскому варианту. Сарафан с рубахой и нарукавником нередко шили комплектом из одной ткани, при этом сохранился обычай оформлять нижнюю часть передника вышивкой. Праздничные варианты таких костюмов хранились в сундуках в течение XIX-XX вв., хотя и вышли из употребления в годы советской власти.

Юбки и итаны. В горных селениях при поездках на полевые работы надевали широкие штаны - чембары - под сарафаны, такого же покроя, как и мужские, и также заправляли в них рубаху. По сообщениям жителей, с изменением покроя сарафанов от штанов отказались, но стали носить юбки, что охотно приняла молодежь. Это послужило как бы переходной ступенью к одежде XX в.

Одежда мужчин была не менее яркой, чем у женщин. Полотняная праздничная рубашка производила особенно сильное впечатление обилием яркого красного цвета и крупной вышивкой преимущественно красно-черными нитками. Хотя покрой рубашек был типично русским, но в нем имелись детали, неизвестные ни в северных, ни в южнорусских регионах. Рубахи были длинными (ниже колен), без воротника, лишь с обшивкой, разрез на груди делали с правой или с левой стороны. Рукава были также длинными, прямыми и широкими (в полторы полосы), под ними к основному полотнищу пришивали, для увеличения ширины, клинья, которые соединяли с рукавом через красную ластовицу. По всем вертикальным и горизонтальным швам тянулись широкие полосы кумача с вышивкой на них черными или реже зелеными нитками. Специфику этих рубах составляла квадратная вышивка под воротником, занимавшая ткань под вырезом для головы вдоль всей длины разреза. В ней обычно присутствовала фигура креста, которая, повторяясь, спускалась вниз и иногда доходила почти до пояса. Вышивка окружала также и горловину и, кроме того, на спине от плечей как бы перекидывались вышитые ленточки. Эти рубахи носили поверх штанов, подпоясав пестрыми плетеными поясами. Праздничную одежду хранили в сундуках до XX в., а в повседневном быту перешли на яркие цветастые рубахи из покупных тканей. На них небольшие полоски вышивки нано- 
сили лишь иногда и по некоторым швам, а богатая вышивка на груди была заменена кокеткой. Рубахи «поляков» и каменщиков имели вариативность, заключавшуюся в расположении вышивок и их большей или меньшей обильности. В начале XX в. у южных старообрядцев начали распространяться косоворотки городского покроя, иногда с кокеткой и небольшими вышивками.

Штаны шили довольно широкими с использованием трех вариантов покроя: а) традиционного русского из трех кусков ткани; б) с расширенным верхом за счет добавления косой полосы, что добавляло удобства для верховой езды; в) чембары - широкие, как шаровары, сшитые из трех прямых полос с широкой вставкой посредине, в дороге их могли надевать поверх теплого верхнего платья. В начале XX в. в местную моду вошли шаровары (особенно в местностях горноразработок). Их шили из дорогих ворсовых материалов (плис, бархат), китайского шелка (на подкладке), а также - из бумажных импортных и российских тканей. Штаны для праздничного костюма украшали вышивкой с растительным геометрическим орнаментом по низу штанин и на боках.

Головные уборы различались по сезонам. В теплое время года носили войлочные округлые шапки, сходные с традиционными гречневеками и плетеные из соломы шляпы. В холодное время надевали утепленные шапки с меховой опушкой, в том числе с квадратным верхом, как в центральных и западных губерниях России. Молодежь «поляков» украшала шапки лентами, цветными шерстяными помпонами, перьями и кистями, свисавшими сбоку. В морозы и в дорогу крестьяне надевали казахские меховые малахаи, закрывавшие шею и уши.

Обувь была также русская и заимствованная. Все сибиряки носили кожаные сапоги, что быстро переняли и ссыльные «поляки». Для работ имелись высокие сапоги - бутыль (бродни) из выворотной кожи с мягкими голенищами, которые подвязывали у колен. В Горном Алтае носили и унты (лунты) - сапоги из шкурок с козьих ног, сшитые мехом внутрь, и такие же, но короткие кисы. Домашней обувью служили короткие коть (чарки) как головки сапог, обшитые мехом или мягкой тканью. Эта обувь была распространена также на европейском Севере и в Приуралье. Зимней обувью служили катанные из овечьей шерсти nимы (валенки). На ноги надевали вязаные шерстяные или протяные чулки, носки. Для молодежи вязали полосатые носки с зубчиками, а «поляки» молодожены прикрепляли к ним кисти (накищз вали). Обувь была одинаковых форм для мужчин и женщин и начинали ее носить с детства.
Верхняя одежда также была сходна у мужчин и женщин, имела преимущественно халатообразный покрой. Рабочую одежду шили из сукна или полусукна (щабур, зипун, пониток) с прямой спинкой. В горных районах их называли подоболочка, для мужчин имелся вариант с подрезной спинкой (кафтан), который надевали в молельню. На юге Алтая вошли в обиход халаты. Их предпочитали покупать готовыми у казахов, для лета из китайского или бухарского тафтяного шелка или бархата; для зимы - стеганые на вате или суконные. Халаты носили также и женщины. Особенно интересна была жубка из красивой ткани с меховой отделкой вдоль широких пол с большим запа́хом. Шубки надевали «в рукава» или «внакид», запахивали на левую сторону так, что могли держать под полой ребенка. Аналогичную одежду издавна носили в южнорусских губерниях под названием «халат» или «тайник».

Как и повсюду в Сибири необходимы были меховые одежды, шившиеся мехом внутрь (шуба, mулуn) или мехом наружу (яга, доха) из шкур дикого козла или марала, а позже - из собачьих шкур. Нагольные шубы красили в черный или коричневый цвет, а зажиточные хозяева покрывали их сукном или китайкой.

Все виды одежды обычно подпоясывали яркими длинными поясами с кистями или бахромой, что придавало яркости. Помимо этого, праздничную одежду обогащали специальными навесками из шерстяных шнуров с добавлением бисера, женщины плели бисерные решетки - ряски, как накладные воротники или бармы. Бисерные нити и ленты мужчины и женщины подвешивали к головным уборам и на шею (гайтань), что увеличивало яркость костюма, выделявшего южных старообрядцев среди других сибиряков. Им удалось создать своеобразную культуру одежды, объединив в ней черты разных славянских народов и воспринятое от населения соседних стран. Специфика костюма стала знаковым элементом, как бы подчеркивающим устойчивость и жизнеспособность жителей пограничных селений.

C конца XIX в. яркие фабричные ткани постепенно вытесняли холст, одежда городского типа постепенно проникала в горы. Ее стали воспринимать сначала предгорные «поляки», процесс усилился после 1920-1930-х годов, продвигаясь на север в долины Уймона и Бухтармы.

В головных уборах женщин переплетались северно- и южнорусские традиции, на что указывают названия: кокошник, кичка, шамшура (самшура). В рассматриваемое время наиболее распространена была шамшура, покрытая платком или шалью. 
Шамшура имела вид мягкой шапочки с плотным очельем, у поляков равнинной части его углы называли «рога», как элементы южнорусской кички. У горных бухтарминцев к шамшуре пришивали плотный круглый жгут из ткани - «кишку», а макушку закрывали овальным куском ткани. В равнинной части самшуры имели и закрытую, и открытую макушку головы, когда верхний край шапочки собирали на вздержку. Кокошники были праздничным элементом костюма, уходившим из быта. Их в прошлом шили из дорогих тканей (шелк, бархат) на подкладке, но без плотной основы, как на севере. Кокошники надевали на кичку, по форме сходную с шамшурой, но с плотным, шитым золотом очельем. Сзади подвязывали позатьльник в виде плотной полосы ткани, украшенной позументом и подвешенными нитями бисера. Вся эта сложная конструкция весьма сходна с вариантами южнорусского головного убора. Однако на Алтае голову покрывали сверху платком или шалью. В праздники обертывали вокруг головы чалмообразно, что считалось красивым и у восточных славян, и у тюркоязычных народов. Русские молодые женщины свешивали кисти шали по бокам, оставляя открытым только лицо. К этому дополняли еще цветы (живые или искусственные), укреплявшиеся в чалме. В таком ярком костюме усматривается не только переплетение разнородных традиций, но пополнение их местными находками.

Традииии питания у старообрядцев-каменщиков формировались и развивались так же, как и у других групп старожилов Сибири. Однако темпы изменений были различны, соответственно, с историей заселения и условиями проживания местных групп. При этом у всех ярко выступало сохранение многого древнего на фоне включения нового.

Жители горных ущелий, переселившиеся из восточных округов Западной Сибири, будучи беглецами, ограничивали контакты с равнинными местностями и до конца XIX в. сохраняли севернорусские традиции. Они смогли лишь внедрить в суровой природной среде основные культуры североевропейского региона, обеспечивая весьма скупое пропитание. Отыскивая плоские участки на горных склонах, на более северных сеяли озимую рожь и понемногу пшеницу, так как она «годом родится», на южных - яровые: овес и ячмень. Соответственно, хлеб со времени поселения пекли ржаной, небольшими ковригами. Пшеничный хлеб получался серым, поскольку зерно плохо вызревало и плесневело. Перемены начались уже в ХХ в. и пришли с равнины, где с конца XIX в. активизировалось расширение ярового поля. Также в горных селах стали высевать яровые: пшеницу, овес, яч- мень. Пшеничный хлеб вышел на первое место, в Бухтарме его выпекали в форме калачей средних размеров (диаметр до 25 см). В европейской части эти изделия относятся к улучшенной выпечке, на юге Алтая праздничная выпечка делалась в севернорусском варианте: чиньги, каралики и т. п., пекли также медовые пряники из крупы, преимущественно ячменной, как и у всех старожилов Сибири. В постные дни основным блюдом являлись mолстые шти, близкие к каше, которые заправляли мукой, имелись жидкие шти (не постные) и похлебка с куском мяса. Кашу в посты варили на воде, в скоромные - на молоке с топленым маслом.

Мясная пища была весьма обильна, так как держали много скота разных пород, ели даже свинину, но «очищали» животных, выдерживая их в «засадке» 40 дней. В большом количестве разводили птицу, немало поступало продуктов охоты. Мясо жарили и варили, на стол подавали порезанным в отдельном блюде. При обилии рек и озер много к столу поступало рыбы, заменявшей мясо в постные дни. Молочные продукты также были обильны. Их использовали, как и повсюду в Сибири, с применением замораживания.

Овощеводство при начале расселения было слабо развито, как у всех старожилов. Скудный набор северных видов выращивали на огородах. При этом много использовали даров природы: ягод и трав. На зиму заготавливали кадушками засоленные местный лук и чеснок, которые собирали в гоpax. Эту острую зелень любят и жители равнины, особенно калбу, которую набирали возами и вывозили для продажи. Зимой заготовки подавали к столу, разводили квасом и ели с хлебом. Своеобразно запасали на зиму хрен: его натирали и сушили и добавляли в готовые блюда. От местных жителей русские узнали свойства многих лечебных растений, некоторые использовали в пищу (в похлебки, пироги), например ревень, марьино коренье, сарану. Китайский чай, ради получения которого был проложен в горах Чуйский тракт, приняли староверы-поповцы («австрийцы»), беспоповцы считали «китайскую травку» запретной, но молодежь отваривала черные листья бадана, обладающие тонизирующим и вяжущим свойствами. Независимо от отношения к чаю, в конце XIX в. практически во всех семьях появились русские самовары и китайская фаянсовая и фарфоровая чайная посуда, а в лавках продавали китайский развесной и кирпичный чай. Повседневным напитком, как и повсюду у русских, был хлебный квас, его подавали на стол к каждой трапезе. К праздничным пирам завозили пиво-солодуху, для строго постящихся - пиво-травянушку с настоем из семи трав, иногда - легкое 
сладкое пиво-медовуху. Водка и самогон не допускались.

Мед в горных селеньях был необходимым элементом питания. Его в пост ели с хлебом по утрам, добавляли в каши и смешивали с ягодными заготовками, киселями, варениями, он же являлся важным лечебным препаратом и существенным элементом торговли с равнинными селениями. К концу XX в. в питании горцев стали проявляться изменения, связанные с расширением сельского хозяйства.

Новшества приходили от южных соседей, «поляков». Они представляли движение с запада, от украинско-белорусского пограничья. Ссыльные принесли новые сорта яровых злаков и более совершенную технологию выращивания. Посевы пшеницы вышли на передовые позиции, одновременно на полях появились теплолюбивые овощи, начало развиваться садоводство.

Система питания ссыльных «поляков» строилась на традициях южнорусского, украинского и белорусского народов, была разнообразна и этим обогатила пищу всех старожилов Западной Сибири. Большое значение имело развитие полеводства, в первую очередь пшеницы. Попав на благоприятные черноземные земли, «поляки» год от года увеличивали посевы и получали богатые урожаи. С этого начался выход русского зерна на общероссийский, а затем и на мировой рынок. Посевы других яровых культур обеспечивали разнообразие каш. Однако зерновые продукты играли значительно меньшую роль в питании, чем у старожилов, но обогатили их праздничную выпечку и особенно жидкие блюда.

«Поляки» готовили супы с овощами: щи (шти), включая в них не менее трех видов овощей, в борщи - еще больше. Появилось много выпечки с начинкой из овощей и фруктов. При этом приехавшие перенимали хорошие блюда и от местных жителей. Так, для начинки пирогов использовали некоторые местные травы и любимую старожилами черемуховую муку (из высушенных ягод). Пельмени, принесенные в Сибирь старожилами, стали любимым блюдом и для «поляков».

Скотоводство «поляков» отличалось от других групп южных старообрядцев иным отношением к животным. Состав стада был традиционным для русского хозяйства, но в обширных сибирских усадьбах для скота отводили больше места: имелись срубные крытые дворы и открытые участки $($ пригоны) для дневного содержания. Когда хозяйство расширялось, часть скота содержали на за- имках, кроме того, переняли от коренных жителей обычай отгонного животноводства: местная природа позволяла наращивать стадо. Особую роль сыграло молочное животноводство. В конце XIX в. молоко коров сибирского качества было признано лучшим. В начале XX в. был создан Союз сибирских маслоделов, затем Союз алтайских маслоделов, которые способствовали созданию крестьянских артельных заводов. Сибирское топленое масло вывело Россию на мировой экспорт. На успехах молочного животноводства выросли эффективное свиноводство и картофелеводство, которым ранее у старожилов не уделяли внимания. Хозяйственные успехи благоприятствовали улучшению быта крестьян, но сохранялись и древние северные традиции. По уровню жизни и разнообразию питания «поляки» резко отличались от горных групп и отчасти передавали им хозяйственные навыки.

\section{Пореформенные переселенцы}

Крестьяне европейской части страны, получившие возможность переселяться в Сибирь, попадали в неодинаковые условия. Переселение в Алтайский округ было разрешено позднее, чем в другие губернии Западной Сибири, и при этом с требованием получать разрешение от местных крестьян «приписаться» в их сельское общество. Это ставило приезжих в зависимое положение. Однако распространявшиеся слухи об обширных землях с хорошими черноземами манили надеждой на лучшую жизнь. Подселялись сначала в деревни, позже стали осваивать брошенные заимки. Старожилы, когда в селениях накапливалось много приезжих, оставляли дома и уходили к югу. «Откочевывали в горы, да их и было-то немного», - сообщали нам жители старинных поселений. «Российские», как называли новоселов старожилы, проживали в каждом из посещенных нами населенных пунктов и во многих преобладали. В конце XIX в. переселенческое управление начало регулировать движение, направляя прибывавших в местности, близкие по природным условиям к их родине. Появились районы более-менее компактных группировок выходцев из смежных губерний: из Пермской, Вятской, Вологодской отправляли в восточную лесистую часть края, из южнорусских губерний, Украины, Белоруссии и др. - в центральную и западную степные части.

Переселенцы северо-восточной части региона ${ }^{5}$

Как только было официально разрешено переселение в Алтайский округ, началось движение

\footnotetext{
${ }^{5}$ Район работ: 1978 г. - Крутихинский район (Волчно-Бурла, Прыганка, пос. Покровский); Солонешенский район (Сростки, Екатерининское, Карачайка); Усть-Пристанский район (Клепиково, Камышенка, Егоровка); 1980 г. - Тогульский район (с. Тогул, Уксунай, Колывань, Локтевка, Сентелек, Мартыновка, Новотроицк, Бутаково).
} 
из ближайших северных губерний. Подселялись в деревни старожилов и на выделенные участки. Прибывшие попадали в таежные леса, как и первые насельники, им приходилось расчищать места под строительство. Началось активное уничтожение лесов. Старожилы вырубали лучшие участки, чтобы они не достались «чужим», новоселы рубили все подряд. Корреспондент РГО из с. Верх-Тогул сообщил, что переселенцы вырубили «мелкие и крупные березняки, рощи и дубровник. Черни отодвигаются вглубь, местность оголяется» [11].

Расселение, поселения. Для изучения этой темы, помимо опросов и наблюдений, было привлечено много архивных документов и текущих разработок сельских планирующих и архитектурных учреждений. По архивным документам и сообщениям жителей, было выяснено, что малодворовые деревни старожилов первоначально имели разбросанную застройку или так называемую кучевую планировку. Когда подселения новоселов были единичны, планировка сохранялась. Когда прибывала группа переселенцев, то застраивались отдельными порядками или улицами (линейная планировка), как было принято в европейской части страны. В один населенный пункт нередко прибывали переселенцы группами из нескольких губерний. Каждая из них отстраивала свою улицу, создавая радиальные формы с несколькими конияами, которые обычно называли по местам выхода: Тамбовский конец, Рязанский конец и т. п.

При расселении прибывавших Переселенческим управлением новоселов направляли на выделенные участки, распланированные по линейному плану порядками или улицами. Однако поток переселенцев превышал расчеты землемеров, новая застройка создавала концы, переводя линейный план в вилочную или радиальную формы, которые в XX в. стали преобладающими.

Жилище вновь прибывавшие строили из более мелкого леса. Они возводили дома в тех же северорусских традициях: рубка домов в угол, на довольно высокой подклети. Внутренняя планировка сохранялась севернорусская с печью у двери, но высокий голбец уже был заменен на низкий или на люк в полу, как и по другую сторону Урала. Стены внутри домов продолжали подтесывать, но новые переселенцы обходились без росписи, что было дорого. Однако наружный резной декор сохранялся, включая пропильные доски, которые чаще встречались в новой застройке. Усадьбы соответствовали среднерусской замкнутой традиции, с чистым двором возле дома, задним скотным двором и неизменной баней. Однако количество хозяйственных построек стало меньше.
В годы советского строя вследствие сокращения размеров приусадебных участков и перехода к коллективному ведению хозяйства этот процесс распространился также и на старожилов.

Одежда сохраняла традиционный севернорусский комплекс. Переселяться на юг стали в первую очередь старообрядцы, так как жителям европейской части были хорошо известны места поселений староверов за Уралом.

Женская одежда. Приезжие женщины приносили свою одежду, сшитую в основном из домотканины, но по мере обзаведения хозяйством для праздничной приобретали покупные, в том числе зарубежные ткани. Основной комплект костюмов включал рубаху с прямыми поликами и сарафан. Покрой сарафанов стал более разнообразным: как с узкими, так и с широкими лямками, с разными вариантами расклешивания, позднее появились сарафаны с отрезным лифом и прямые со сборками, а также комплект парочка - сарафан и рубаха, сшитые из одной ткани. В конце XIX начале XX в. сарафанный комплекс активно стал вытесняться более современным комплектом из юбки и кофты различных фасонов, приносимых новоселами из Центральной России. Его носили с передником, по большей части поясным, длинным, украшенным по низу воланом или оборкой.

Головные уборы в этот период составляла самшура с закрытой макушкой, на которую по праздникам надевали мягкий кокошник в виде шапочки на подкладке с плотным вышитым верхом. В повседневном обиходе самшуру покрывали платком.

В мужской одежде также в первое время преобладала домотканина, в том числе пестрядь и тяжовина (в полоску). Мужчины носили руба$x и$-косоворотки с разрезом слева и невысоким воротничком-стоечкой, а также штаны традиционного покроя или более широкие щаровары, а в Сибири к ним добавили чембары. Однако в этот период сельские жители уже сменяли традиционную одежду на городскую: штаны с поясом или ремнем и с карманами, рубашки с отложным воротником, а также пиджак или куртка.

В качестве верхней одежды сохранялись известные в северных губерниях понитки, шабуры, кафтаны, которые стали дополнять городские куртки. Зимняя одежда объединила приезжих и старожилов. Овчинные щубы прямого и халатообразного покроя носили мужчины и женщины. Подрезные в талии полушубки считались мужской одеждой. Их носили с меховыми шапкамитреухами и с утепленной суконной шапкой с меховой опушкой. В дороге все пользовались тулупами из овчины с большим воротником, пересе- 
ленцы шили их также из собачьих шкур. В начале XX в. женщины стали носить стеганные на вате пальто с суконным и плисовым верхом, которые, как и в европейской части страны, называли сак и полусак, у мужчин появились теплые суконные куртки и полупальто.

Обувь у переселенцев была разнообразнее, чем у сибиряков. Из Приуралья привозили плетеные лапти и кожаную короткую и высокую обувь. Лапти некоторое время держали для хозяйственных работ, а в повседневном быту предпочитали севернорусские коты (обутки) - короткие, сходные с головками сапог, утепленные по верхнему краю мягкой обшивкой со шнурком. Мужчины носили бахиль без каблуков, с высоким голенищем, которое подвязывали у колен. Мужчины и женщины в праздничные дни надевали кожаные сапоги, а зажиточные с конца XIX в. привозили башмаки и ботинки. Их носили с шерстяными или холщовыми чулками, как это было принято у русских крестьян.

В питании переселенцев на севере русских губерний, а также переселившихся из Тобольской и северной части Томской губерний присутствовали традиции, бытовавшие у местных русских старообрядцев. Крупо-мучной рацион с толченым ячменем, любовь к ржаному хлебу, преобладание продуктов животного происхождения (говядина, баранина, рыба из местных водоемов). Однако в XIX в. изменилось направление хозяйства в северных губерниях, где больше стали выращивать пшеницы, разнообразились овощные культуры, и эти новшества распространялись на новом месте жительства. Постепенно уходили со стола горячие затирки, но толстые щи оставались любимым блюдом. Горячая пища пополнялась похлебками (отварное мясо с картофелем) и щзами (похлебка с добавлением капусты). Любимым и праздничным блюдом стали пельмени, еще ранее занесенные переселенцами из Приуралья. За время их пребывания в Сибири сложился местный вариант приготовления, и уже из пшеничной муки. Маленькие лепешечки нарезали от жгута из теста, набивали фаршем из любого мяса или смеси разных видов, фигурно защипывали и обертывали вокруг большого пальца, чтобы было похоже на округлое ушко. В это же время увеличилось разнообразие овощных культур, появился местный сорт крупных сибирских огурцов, больше стали сажать картофеля. Однако в основном сохранялся стиль питания сибиряков-старообрядцев.

\section{Переселенцы центральной части региона ${ }^{6}$}

Центральная часть Алтайского округа начала заселяться несколько позднее северо-восточной части, а поток переселенцев был намного мощнее. Его представляли жители центральных и южнорусских губерний страны, проникавшие во все старожильческие селения вплоть до Горного Алтая. В какое бы селение старожилов ни приезжал наш отряд, основными жителями оказывались переселенцы. Жители говорили, что сибиряки «все побросали и ушли, в горы откочевали». Однако часть сибиряков оставалась, например, они проживали в старожильческих селениях с. Коробейниково и Зеркалье и Шипуновского района. По расспросам было выяснено три пути освоения земельных владений старожилов: 1) подселение на окраины деревень, с условием пользования угодьями с выплатой так называемых «полеток», 2) самовольное заселение брошенных заимок с последующим оформлением селения в Переселенческом управлении и 3) выделение брошенных угодий ПУ как арендных участков. После революции советская власть организовывала на бывших заимках коммуны, совхозы и колхозы.

Планировка селений складывалась большей частью произвольно с использованием построек прежних жителей. Прибывавшие партии переселенцев застраивались улицами и порядками, с учетом рельефа. Если вселялись партии из разных губерний, то возникала радиальная планировка «концами» для каждой группы отдельно. Поселки совхозов и МТС застраивали по линейному плану архитекторов.

В жилище наблюдалось сочетание традиционного: старожилов и переселенцев, а также новой советской застройки. Лучшая часть прежнего жилого фонда была передана под государственные учреждения, часть использовали приезжие, подстраивая под свои надобности. Прибывавшие партии из южнорусских губерний начинали новое строительство по традициям родных мест. С увеличением потока переселенцев, чтобы избежать хищнической вырубки, администрация разработала «Инструкцию о переселенцах», согласно которой по прибытии на место им должны были выделять «от 30 до 40 корней на семейство». Этого было недостаточно для строительства дома, к тому же приходилось использовать лиственные породы, на них переселенцы перенесли традиции обмазки стен глиной. Хуже было положение самовольных «непричислен-

\footnotetext{
${ }^{6}$ Район работ: Шипуновский район (с. Шипуново, пос. Родина, д. Быстрянка, Калмыцкие Мысы); Поспелихинский район (пос. Горьковский,
} пос. Вавилон, Шипуниха); Мамонтовский район (с. Суслово, Рубцовск). 
ных» переселенцев. Они не получали леса и были вынуждены добывать его топором. Леса продолжали вырубаться.

Переселенцы строили наземные дома, в большинстве с земляным полом и под соломенной или камышовой крышей. Во внутренней планировке появилось южнорусское положение печи у фасадной стены и с полом - настилом у печи. Однако познакомившись с традициями сибиряков, новоселы переходили к местной планировке с печью у входа, что более подходило для сибирского климата. При этом дымоход делали не прямым, а с изгибом на чердаке, что, по-видимому, являлось отголоском выведения его к дымарю в сенях, который ставили в прошлом в южной России. При опросах встречались воспоминания о плетеных дымарях, но к середине XX в. они исчезли.

Усадьбы старожилов также претерпевали изменения. В начале XX в. в связи с развитием сельского хозяйства и промысловой деятельности огороженные замкнутые усадьбы пополнялись новыми постройками: появилось по несколько амбаров, местные маслозаводы, бондарные мастерские и пр. В годы советской власти при создании коллективных хозяйств многие из этих строений обобществляли и вывозили с усадеб на окраины. Размеры усадеб были сокращены для ведения индивидуального хозяйства, также число построек на них.

Особенно серьезные изменения наблюдались при создании коммун. В них объединялись беднейшие из переселенцев, без жилья и хозяйства. На общем собрании принимали решения: закупить «малушки» для каждой семьи или построить общий дом-коммуну. Комплексное решение было найдено в коммуне «Майское утро» (позже колхоз им. Молотова, затем - «Родина»). По решению собрания купили семь малушек и в каждой поместили по две семьи. Однако общая установка была на быстрое и ударное развитие хозяйства: хлебопашество, садоводство и пчеловодство. Первые коммунары приехали из Украины, потом подселялись русские. С увеличением населения и при хозяйственных успехах было принято новое решение - строить на каждую семью современные дома, к тому же - на хозяйственные доходы. Приглашенный архитектор рекомендовал сдвоенные дома из собственных материалов. Для этого был построен кирпичный заводик, как в безлесных районах европейской части страны, а также налажено производство черепицы, чего в Сибири ранее не практиковали. Внутреннюю планировку приняли местную, с русской печью в кухне и с подпольем, имевшим вход через люк.
Тем самым коммуна «Майское утро» положила начало новому сельскому строительству на счет общественных и государственных средств с использованием нетрадиционных строительных материалов. Оно развилось в конце XX в. при широком включении дерева от местных артелей, кирпича заводского производства, панельных плит и даже целых секций. Также в коммунах закончилось и прежнее господство севернорусского расположения печи, в новых зданиях их помещали посредине между комнатами, у боковых стен, а иногда обходились плитами с конфорками. При колхозном и совхозном строительстве на государственные и хозяйственные средства в селениях начиная с 1960-х годов стали вводить проектирование как для индивидуальных, так и для колхозных многоквартирных построек. Это оказало влияние также на увеличение размеров частных домов и на усложнение их внутренней планировки с разделением площади по бытовому функционированию. С 1970-х годов в связи с проектом перепланировки сельских населенных пунктов приступили к строительству зданий в несколько этажей (до четырех) с улучшенной планировкой по образцу городских квартир. Одновременно в крупных селениях началась частичная газификация, установка парового отопления и канализации. Однако, как показали полевые наблюдения, большая часть населения продолжала до конца $\mathrm{XX}$ в. проживать в индивидуальных домах с приусадебными земельными участками.

Одежда в центральной части Алтайского округа демонстрировала наиболее разнообразное сочетание традиций восточнославянских народов. Практически в каждом селении уживались представители различных национальностей и этнографических групп. По всей вероятности, это определяло и сравнительно быстрый переход к городскому костюму того времени. Жители называли два конкретных повода к изменениям: 1) создание коммун, в которых нередко шили новую одежду, одинаковую для всех вступивших, 2) коллективизацию, в период которой «старые фасоны побросали». В действительности причин выявлено больше. Имело значение улучшение снабжения сельских жителей тканями заводского производства, готовой одеждой и обувью, развитие торговой сети и пошивочных мастерских, peкомендации СМИ и т. д., а главное, имел значение состав переселенцев в каждом населенном пункте и отношение к традициям и новшествам в разных возрастных группах.

В конце XIX - начале XX в., как показали полевые наблюдения, вариации традиционных 
костюмов быстро нивелировались в селах, где сохранялось старожилое население. Молодежь завистливо считала, что все они «в шелке, бархате ходили». Девушки нанимались батрачить, чтобы обзавестись одеждой местной группы. Хозяйки иногда одаривали работниц из своего гардероба и даже «справляли парочки». К новой одежде у приезжих было особо бережное отношение: «юбку одну сошьешь и носишь ее лет 20» (с. Быково, Шипуновский район, 1965 г.). В селениях, где собирались приезжие из разных губерний, первоначально господствовала пестрота: «Ходили по-разному: кто в платьях, кто в сарафанах, кто в юбках» (пос. Горьковский, Поспелихинский район). Дольше удерживались в одежде переселенцев сарафаны, хотя они и отличались по покрою: у сибиряков «на груди узкий, а внизу - широкий, широкий, а у нас - лиф отрезной» (с. Калмыцкие Мысы, переселенка из Шацкого уезда Рязанской губернии).

В этот же период начал распространяться новый комплект - парочка (юбка и кофта), который подхватила молодежь всех групп населения. Он оказался наиболее практичным и удобным, перешагнул в советский период и был дополнен в повседневном быту фартуком. Старшее поколение сохраняло традиционную одежду почти до конца жизни. Особенно долго она удерживалась там, где преобладали выходцы из одной местности. Так, в пос. Родина заселились украинцы, они носили вышитые рубашки, юбки в клетку, киптарь, свиту. К тому же украинский костюм отчасти соответствовал принятым у богатых старообрядцев вышитым рубахам, широким юбкам и шароварам, а чембары были восприняты и приезжими, их носили зимой даже в 1960-е годы. В то же время переселенцы из центральных губерний страны приезжали в парочках, которые начинали распространяться и в Сибири. В начале XX в. у большинства жителей региона преобладали в гардеробе юбки и кофты разных фасонов.

\section{Переселенцы западной части региона}

К концу XIX в. земли центральной части Алтайского округа были заселены уже весьма плотно и переселенческое движение стало смещаться к западу в лесостепную и степную части. В 1885 г. был создан Западно-Сибирский переселенческий отряд для размещения прибывавших из России. Западная часть была слабо заселена, так как была засушливым, без крупных рек, местом с засоленностью почвы и некоторых озер. Почти треть отведенных участков не имела водоемов. В эту мест- ность направляли выходцев из степных губерний России и Украины.

Поселенная структура. Жилищное строительство создавались в малоблагоприятных условиях сухих степей. Землемеры нарезали участки усадеб, создавая уличные планы населенных пунктов (линейную планировку), которая в это время уже господствовала в европейской части страны. При размещении переселенцев им должны были выделять древесину на строительство дома в соответствии с указом Переселенческого управления, но в недостаточном количестве. Поэтому построить срубный дом могли лишь прибывавшие с деньгами, остальные вынуждены были обратиться к древним народным традициям строительства из глины.

Первые из попадавших в степь строили примитивные землянки и полуземлянки (копанки), которые складывали из нарезанных пластов дерна. Дерн складывали по периметру будущей постройки, внутреннюю площадь углубляли примерно на полметра. Кровлю делали из жердей, на которые укладывали также дерн или солому и промазывали глиной. Собрав средства, приступали к постройке постоянного жилища, используя навыки, применявшиеся в степных регионах для построек из глиносоломенных смесей (в технике саманной, вальковой или глинолитой с применением каркаса из дерева). Эти дома были наземными, крытыми соломой или камышом под глиной. Снаружи также обмазывали здания глиной и обычно белили, как на Украине. Внутренняя планировка стала более разнообразной, так как каждая группа прибывавших оформляла дом по своим традициям, в основном южно- и западнорусским, с печью у фасада, с устьем ко входу или в боковую сторону. Все дома были наземными, в начале расселения - с земляным полом (земь), с «полом»-настилом, со входом с улицы.

Дефицит строительного леса побудил администрацию в XX в. способствовать распространению каркасной техники и даже вводить новые материалы. Местная промышленность освоила производство шлакобетонных блоков и камышитовых плит для индивидуального и колхозного строительства. Тем самым западные районы стали местом апробации материалов, ранее не применявшихся в Сибири. Отсюда новшество переносили в центральный регион, леса которого сильно пострадали от деятельности человека. Со степных регионов в конце XX в. было начато панельное и блочное строительство на обществен-

\footnotetext{
${ }^{7}$ Район работ: Славгородский район (Славгород, с. Владимировка, Семеновка, Яровое, Бурла, Михайловка).
} 
ные и государственные средства. Вошли в обиход также новые кровельные материалы: камыш, дранка и шифер, которому отдавали предпочтение. Одновременно с новыми материалами проходило улучшение размеров и планировки жилища: увеличение световых проемов, выделение кухни и функциональных зон для членов семьи. Как и повсеместно в стране, местные архитекторы и строительные организации предлагали рекомендации, участвовали в планировке, а нередко и в постройке новых домов.

Одежда в западных районах края была намного разнообразнее, чем в других местностях Алтайского края. Переселенцы в начале XX в. прибывали с обширной территории, практически со всей Восточно-европейской равнины, где у каждого этноса имелось по несколько комплектов традиционного костюма.

В женской одежде исследователи отмечали около десятка вариантов покроя сарафанов, поневы распашные и сшитые различным образом, как и более древнюю плахту, а также всем были известны юбки. Основная нательная одежда - рубаха, присущая всем, различалась деталями кроя и декором. Также и все другие элементы одежды бытовали в различных вариантах, отражая многообразие привозимого в Сибирь. Однако оно отступило перед появившимся в конце XIX в. в европейской части страны комплектом женской одежды - парочкой. От центрального региона он быстро распространялся и достиг Сибири, где продолжил вытеснение всех более ранних вариантов традиционной одежды.

У переселенцев западных районов в ХХ в. наблюдалось то же отношение к традиционным комплектам, что и у ранее приехавших в XIX в. Каждая группа прибывала в своих комплектах костюмов, однако в местной сложной этнической ситуации требовались изменения. По нашим наблюдениям, дольше сохранялся сарафан, покрои его были различны, но среди них на первое место вышел прямой (круглыци), который в ХХ в. приобрел современный крой и уменьшился по длине. Он, в свою очередь, уступал по распространенности комплекту из одной ткани, который и составлял парочку, в ХХ в. стали разнообразить ткани и кофточки шили разных фасонов и из различных материалов. Юбки привозили расцветок и фасонов, присущих той или иной группе прибывавших: однотонные, в клетку и в полоску. В ХХ в. молодежь заменяла их на более современные по покрою, которые носили и с традиционными рубашками, и с кофтами новых фасонов. Сложился устойчивый комплект для парочки: нательная рубашка, кофта (навыпуск), юбка, фартук (поясной или с петлей через голову) и платок (косынка, шаль). Одновременно вошли в быт новые предметы женской одежды: облегченная нательная рубашка на бретельках, лифчик и штаны. Их начали носить горожанки, несколько позже приняли сельские жительницы.

В мужской одежде изменения начались в середине XIX в. в европейской части страны. Они были направлены на приближение к костюмам горожан, так как стали активнее контакты, и проявлялось влияние рабочей среды. Штаны холщовые стали шить из фабричных тканей и «побрючному», гашник со вздержкой сменили пояс и ремень, появились карманы. Рубашка полотняная традиционная подходила и для таких штанов, но покупная ткань была лучше по качеству, произошли изменения по крою: появились праздничные формы с кокеткоц̆, со сборками по ее шву и на рукавах (с бубами). Наибольшую популярность получила рубаха-косоворотка с разрезом слева, прикрытым нашивкой-планкой с тремя пуговицами, со стоячим воротничком, застегивавшимся на одну пуговицу. Рубашки носили, как и ранее, по традиции навыпуск, перехватывая ремнем или плетеными опоясками.

Переселенцы XX в. привозили в Сибирь как традиционные формы, присущие их родным местам, так и новые городские. Получили признание также украинский комплект с широкими вышитыми рубашками и шароварами, который местами входил в моду. Все названные варианты бытовали практически до конца ХХ в., но у людей старшего возраста традиционные рубашки выполняли уже преимущественно роль нательной одежды. С середины ХХ в. среднее поколение мужчин постепенно переходило к ношению готовых изделий: рубашки с длинными рукавами (распашные или глухие) с отложными воротничками и брюки фабричного пошива со сменяющимися формами (то зауженные, то расклешенные). Молодежь стала предпочитать рубашки с короткими рукавами (тенниски, футболки) и специализированные (гимнастерки, тельняшки и т. п.). Престижными начали считать вещи, сшитые из синтетики и импортных тканей.

В обуви и головных уборах сложнее всего переплетались традиции восточнославянских народов.

Обувь в европейской части страны различалась по регионам. Для южнорусских губерний характерной считалась плетенная из липового лыка - лапти, которые носили с онучами - длинными отрезками ткани из холста, шерсти, сукна. Однако уже во второй половине XIX в. лапти ста- 
ли преимущественно рабочей или повседневной обувью бедняков, приоритет имела кожаная обувь. Приезжавшие на Алтай переселенцы путь преодолевали в лаптях, но оказалось, что липа в степях не растет. Пробовали плетение из луба гороховника (дикой акации), но и его было мало. В южнорусских губерниях носили мягкую кожаную обувь - поршни (укр. постоль) из одного куска кожи, которым обертывали стопу, делая швы по носку и пятке. Они были близки к сибирским коротким котам, которые вскоре сменили постолы. Сапоги в XIX в. шили на мужской и женской колодке. С этого периода повсюду в России стали входить в обиход новые формы обуви для каждого пола: туфли, башмаки, ботинки, полуботинки, легкие тапочки и прочее.

Головные уборы резко различались у мужчин и женщин. Для замужних женщин действовало общее правило: «не показывать волос», формы покрова четко различались по регионам. Для южнорусских губерний был характерен сложный убор из нескольких предметов, основу которого составляла рогатая кичка, покрывавшаяся фигурным полотном - сорокой. В Сибири головные уборы упростились. Нам рассказывали, что в прошлом в некоторых селах были шапки с высокими углами по бокам, но их названия забылись. Другой вид головного убора - мягкая шапочка с подкладкой или без нее, известная у всех славян, в том числе украинцев и белорусов, - очипок или повойник, некоторое время сохранялась, но общепризнанным женским убором стали платок или шаль. В мужских головных уборах были признаны общераспространенными утепленные шапки с меховым околышем и более или менее высоким верхом, а также треух, позже сменившийся ушанкой. В степных районах мужчины для лета плели шляпь соломенные с полями разной ширины, которые со временем вытеснили кепки и фуражки XX века.

$B$ верхней одежде сохранялись многие древние формы, принесенные еще первыми поселенцами и пополнявшиеся локальными вариантами, вносившимися вновь прибывавшими. Названий употреблялось много, но покрой был сходным у разных групп, у мужчин и женщин и преимущественно халатообразным. Шили верхнюю одежду из плотных материалов домашнего производства (холст, сукно, полусукно), для тепла их подбивали ватой. Более древние формы были прямыми (халат, балахон, зипун, сермяга и др.), более поздние - с клиньями в боковых швах (свита, куцинка, зипун, иушпан и др.), появились приталенные формы с подрезной сосборенной спинкой и укороченные (женская куцинка, мужская куртка или пиджак). Меховая одежда была нагольная и крытая, также халатообразного покроя (uyбы, myлуnь) и расклешенного, с отрезной спинкой (полушубки), укороченные формы без рукавов (корсет, жилет кептарь, каиавейка, шушун). С конца XIX в. верхнюю одежду начали шить из покупных тканей, распашные одно- и двубортные, укороченные и удлиненные, утепленные на вате (сак, полусак, пальто) или только на подкладке (куртки, пальто демисезонное). В конце $\mathrm{XX}$ в. в одежде стали использовать синтетические материалы для непромокаемых плащей и курток и искусственные меха для головных уборов, воротников, отделки, но более всего - для верхней зим-

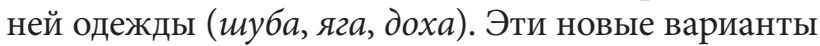
одежды, более легкие и удобные, быстро вытесняли традиционные не только в Сибири, но и по всей стране, являясь частью общемирового процесса.

В питании жителей западных районов наблюдалось разнообразие большее, чем в других сибирских группах населения. Переселенцы из южнорусских губерний сразу же включились в полеводство и в первую очередь развивали хлебопашество. Они привезли новые сорта пшеницы и получали на сибирских землях высокие урожаи, благодаря чему Алтайский край стал в стране основным поставщиком товарного хлеба. Также в овощеводство полевое и огородное были привнесены южные сорта, до того не выращиваемые в Сибири (сахарная свекла, помидоры разных сортов, бахчевые культуры). Садоводство, присущее выходцам из южных регионов, получило новый импульс развития. Также в кулинарии переплетались традиции русских, украинцев и белорусов, к которым добавился опыт жителей Прибалтики, Поволжья и выходцев из других местностей, представители которых частично входили в состав русского народа. Многие блюда поступали в общее пользование (вареники и пельмени, щи и борщи, блины и оладьи, пироги с рыбой, с овощной и фруктовой начинкой и т. д.), но при этом сохранялись внутрисемейные опыты, навыки и предпочтения. Семейные традиции оставались личным достоянием, которым щедро делились за общим столом.

Как показали наши полевые наблюдения, позднее заселившаяся и более сложная по составу группа переселенцев оказалась наиболее разнообразной по переплетению традиций, быстрому включению новых элементов, полученных в Сибири, и со своей стороны внесшей немало новшеств в общесибирское хозяйство и бытовые традиции.

Подводя итог, еще раз укажу, что экспедиционные исследования московских этнологов в Алтайском крае были начаты в 1960 г. и закончены 
в 1991 г. За это время было осуществлено 12 экспедиционных выездов (по 2 мес.) непосредственно в сельскую местность, столько же проведено командировочных выездов в различные города Западной Сибири (в том числе в Барнаул и Новосибирск) для работы в центральных и местных архивах, также были выявлены документы в центральных архивах РСФСР. За это время был накоплен многоплановый и массовый материал, на основе которого опубликованы монографии и статьи, проведены выступления на отечественных и международных форумах. При этом были учтены, рассмотрены и привлечены публикации дореволюционных авторов, а также современные исследования, касающиеся интересующих нас тем.

Историками установлены два основных по времени потока мигрантов в Сибирь (старожилы и переселенцы). Полевые наблюдения этнологов в Алтайском крае позволили выявить, что каждый из них, в свою очередь, разделялся на волны, последовательно осваивавшие те или иные местности в регионе.

Все прибывавшие в Алтайский край последовательно проходили процесс адаптации, имевший различную силу и направленность. Так, все были подвержены воздействию природной среды и стремились найти в крае местности, наиболее благоприятные для быта и хозяйственной деятельности. В этом заключалась, в частности, причина внутренних миграций.

Первые переселенцы, направлявшиеся в северо-восточную часть Алтайского края, селились в местах, близких к кочевьям коренных жителей. В этой местности начались межэтнические контакты и взаимная адаптация народных традиций, затем процесс распространялся к югу по мере расширения русского расселения.

С появлением пореформенных переселенцев новая волна межэтнических контактов, охвативших всю территорию, была сложнее, так как включала взаимосвязи внутриэтнические (между старожилами и переселенцами) и межэтнические (между русскими и представителями других народов России, прибывавшими из европейской части). По ее ходу осуществлялась адаптация к новым, усложнившимся социальным условиям.

Историки проследили общие пути развития хозяйства русского населения в Сибири, традиционно имевшего полеводческо-животноводческое направление. Наши полевые наблюдения под- твердили первоначальную очаговую локализацию полеводческого хозяйства, непосредственно связанного с первым и вторым потоками мигрантов. При этом было установлено превалирование инициативы крестьянства и местных общественных объединений в улучшении сортности культур в полеводстве и породности скота. Целенаправленную селекционную деятельность на государственном уровне начали развивать лишь после установления советской власти.

Вся бытовая культура сибиряков основывалась на народных традициях, перенесенных с мест прежнего жительства. Их утверждение в новом регионе корректировалось местными природными условиями и вновь создававшимися социальными отношениями. В условиях сложной экосистемы Алтая, при непрерывности внешних и внутренних миграций все направления этнокультурного развития протекали как многофакторные и взаимосвязанные явления. Активные процессы адаптации способствовали, с одной стороны, сближению культурных традиций и развитию вариативности, с другой - приводили к отказу от устаревшего и замене на новое, в том числе более соответственное для тех или иных природных ниш региона. При этом в сохранении традиционности и во введении новшеств четко проявлялись половозрастные и вероисповедальные особенности восприятия.

По результатам изучения историками путей формирования постоянного русского населения в Сибири были определены два основных потока миграции, приведших к появлению в начале XX в. двух историко-культурных групп. Полевые исследования московских этнографов во второй половине XX в. позволили выделить в каждой из них по три локально-этнографические группы, сложившиеся в конкретных местных условиях.

Каждая из них обладала набором характерных черт, и при этом в каждой сохранялись специфические этнические черты, более устойчивые в семейном быту. Все вместе историко-культурные и этно-локальные группы демонстрировали вариативность традиций, присущую русскому этносу, и общие черты, объединяющие народ в единое целое.

Полевые наблюдения московских этнологов закончились в 1991 г. [12, 13], но процессы этнокультурного развития продолжались. В их изучение включались местные специалисты. 


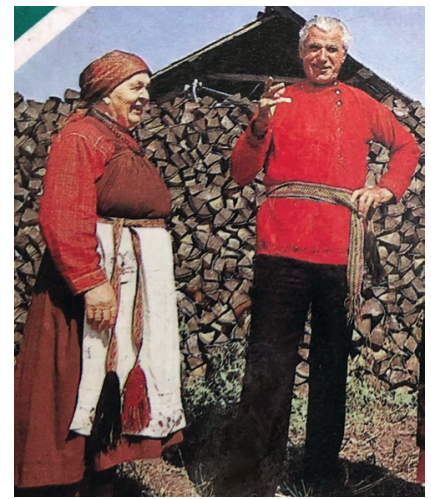

Рис. 1. Сибиряки-старожилы в традиционных костюмах, с. Солонешное

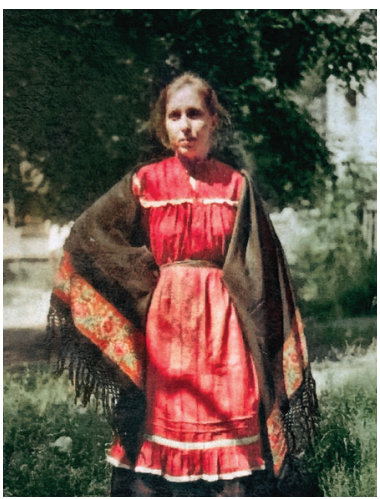

Рис. 2. Женский праздничный костюм нач. XX в. (юбка, кофта, фартук, шаль), Рубцовский р-н

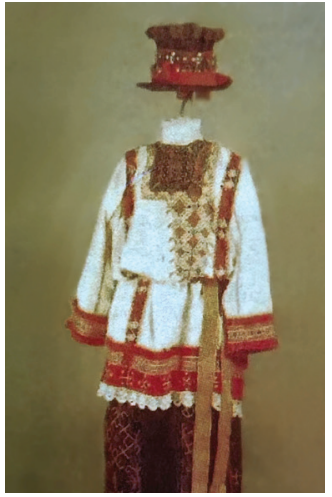

Рис. 3. Праздничный костюм юноши«поляка» (манекен). Музей с. Бутаково, Восточно-Казахстанская обл.
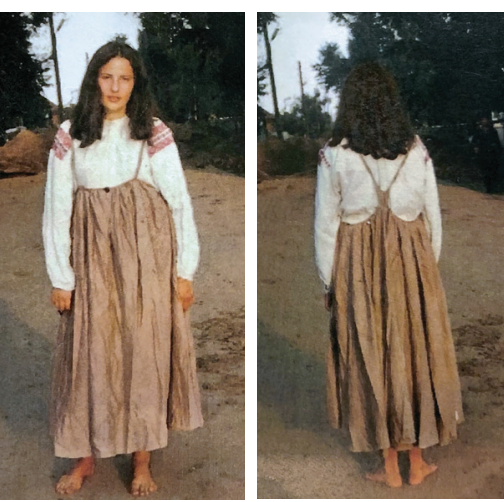

Рис. 4. Женщина в «круглом» сарафане и в рубашке с «прямыми поликами», с. Тогул (вид спереди и сзади)

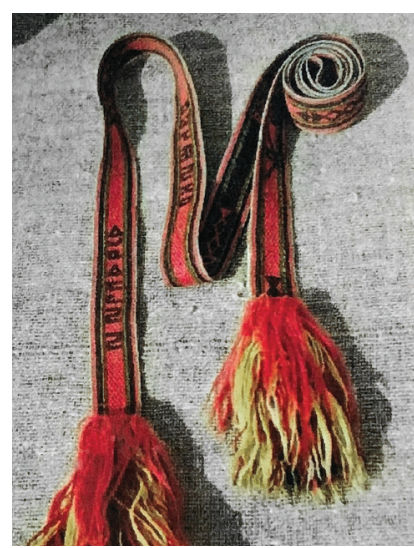

Рис. 5. Подарочный пояс с вытканной надписью, Восточно-Казахстанская обл.
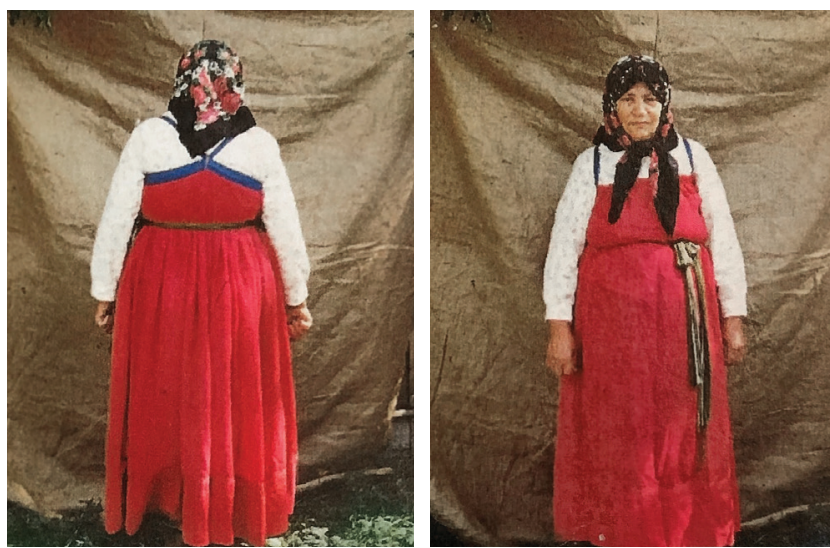

Рис. 6. Женщина, переселившаяся из южно-русской губернии, с. Владимировка, Славгородский р-н

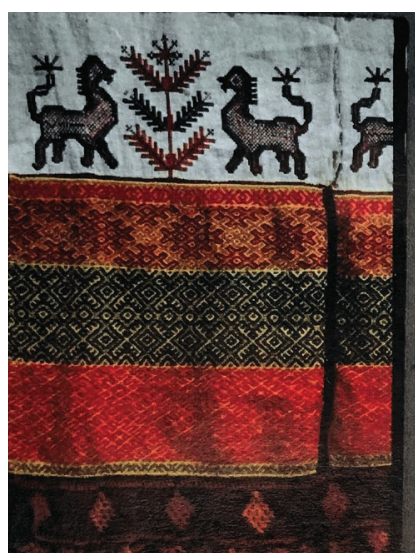

Рис. 7. Полотенце с традиционной вышивкой и подшитыми ткаными узорными полосками,

Славгородский р-н

\section{Библиографический список}

1. Русские. Историко-этнографический атлас. Земледелие. Крестьянское жилище. Крестьянская одежда. Середина XIX - начало XX века / гл. ред. С. П. Толстов и др. М.: Наука, 1967. 358 с.

2. Липинская В. А. Современная материальная культура русского населения Алтайского края: дис. ... канд. ист. наук. М., 1968. 211 с.

3. Липинская В. А. Русские крестьяне на юге Западной Сибири: Развитие традиционной культуры, XVIII - начало XX в.: дис. ... д-ра ист. наук в форме науч. докл. М., 1999. 63 с.

4. Сафьянова А. В. Положение и роль женщины в семейном и общественном быту в русской деревне Алтайского края: вторая половина XIX-XX вв.: дис. ... канд. ист. наук. М., 1973. 196 с.

5. Этнография русского крестьянства Сибири, XVII - середина XIX в. / отв. ред. В. А. Александров. М.: Наука, 1981. С. 242-268.

6. Полевые исследования по этнографии и устной истории на территории Алтайского края во второй половине XX - начале XXI в. URL: http: //etnografy.altspu.ru/ (дата обращения: 19.12.2020).

7. Этнодесант-22: интерактивная карта народов Алтайского края. URL: http://etnodesant.altspu.ru/ (дата обращения: 20.12.2020).

8. Булыгин Ю. С. Первые крестьяне на Алтае. Барнаул: Алт. кн. изд-во, 1974. 144 с.

9. Потанин Г. Н. Полгода в Алтае // Русское слово. СПб., 1859. № 9.

10. Бухтарминские старообрядцы / ред. изд. С. И. Руденко. М.; Л.: Издание АН СССР, 1930. 460 с.

11. Государственный архив Алтайского края (ГААК). Ф. 81. Оп. 1. Д. 42.

12. Липинская В. А. Русское население Алтайского края: народные традиции в материальной культуре (XVIIIXX вв.) / отв. ред. В. А. Александров. М.: Наука, 1987. 224 с.

13. Липинская В. А. Старожилы и переселенцы: Русские на Алтае, XVIII - нач. XX в. М.: Наука, 1996. 267 с. 